\title{
Studi Penelusuran Aliran Pada Sungai Krueng Meureubo Kecamatan Meurebo Kabupaten Aceh Barat
}

\author{
Muhammad Ikhsan ${ }^{1}$, Meidia Refiyanni ${ }^{2}$, Dewita Nazimi ${ }^{3}$ \\ 1,2,3 Jurusan Teknik Sipil Universitas Teuku Umar, Meulaboh, Aceh Barat \\ e-mail: m.ikhsan@utu.ac.id, ${ }^{2}$ refiyannim@gmail.com, ${ }^{3}$ dewita.nazimi93@gmail.com
}

\begin{abstract}
Abstrak
Penelusuran banjir dapat disebut sebagai suatu prosedur untuk memperkirakan/meramalkan waktu dan besaran banjir yang akan terjadi di suatu titik berdasarkan pada data yang diketahui. Tujuan dari dilakukannya penelitian ini adalah untuk mengetahui debit aliran sungai pada DAS Krueng Meureubo dan mengetahui karakteristik hidrograf di bagian hulu dan hilir dengan menggunakan metode Muskingum. Data yang digunakan pada penelitian ini berupa data sekunder yaitu data curah hujan harian dan peta topografi. Besarnya intensitas curah hujan yang tertinggi terjadi pada periode ulang 10 tahunan dan terendah terjadi pada periode ulang 2 tahunan. Nilai Koefisien ( $k$ ) 3400 s dan nilai x 0,462. Hasil penelitian ini menunjukkan bahwa debit puncak inflow di dapat 36,543 $\mathrm{m}^{3} / \mathrm{s}$, sedangkan nilai debit puncak outflow $35,934 \mathrm{~m}^{3} / \mathrm{s}$. Hidrograf aliran dengan metode Muskingum tersebut tampak bahwa perbedaan nilai awal masukan outflow tidak berpengaruh besar terhadap debit yang dihasilkan, nilai debit yang dihasilkan hampir sama hingga akhir hidrograf. Dari hasil penelitian ini diharapkan dapat menjadi acuan bagi pihak terkait untuk melakukan tindakan pencegahan atau mengurangi dampak dari bencana banjir, dan membangun sistem peringatan dini sehingga masyarakat bisa mempunyai sistem kesiapsiagaan.
\end{abstract}

Kata kunci-Banjir, Penelusuran Aliran, Sungai Krueng Meureubo, Muskingum.

\begin{abstract}
Flood routing can be called a procedure for estimating / predicting the time and magnitude of the flood that will occur at a point based on known data. The purpose of this research is to know the flow of river flow in Krueng Meureubo watershed and to know characteristic of hydrograph in the upstream and downstream by using Muskingum method. The data used in this research is secondary data that is daily rainfall data and topographic map. The highest intensity of rainfall occurred in the 10th return period and the lowest occurred in the second return period. Coefficient value $(k) 3400 s$ and value $x 0.462$. The results of this study indicate that the peak inflow discharge at $36,543 \mathrm{m3} / \mathrm{s}$, while the peak discharge outflow 35.934 $\mathrm{m} 3$ / s. The flow hydrograph with the Muskingum method shows that the difference in the initial value of the outflow input does not have a large effect on the resulting discharge, the resulting debit value is almost equal to the end of the hydrograph. From the results of this study is expected to be a reference for related parties to take preventive action or reduce the impact of flood disaster, and build an early warning system so that people can have a preparedness system.
\end{abstract}

Keywords-Flood, Flow Routing, Krueng Meureubo River, Muskingum 


\section{PENDAHULUAN}

$\mathrm{S}$ ungai Kreung Meuerebo merupakan salah satu sungai yang terdapat di kota Meulaboh Kabupaten Aceh Barat. Pada kondisi hujan dengan intensitas tinggi sungai ini sering terjadi luapan/banjir yang menggenangi perumahan penduduk di sekitar hilir sungai ini. Banjir merupakan permasalahan umum yang terjadi di sebagian wilayah indonesia, terutama di daerah padat penduduk misalnya kawasan perkotaan. Bencana banjir ini banyak dirasakan masyarakat baik di kota maupun di desa, keadaan ini diperburuk lagi dengan adanya proses konversi lahan atau perubahan tata guna lahan yang berlangsung cepat sampai ke pedesaan, proses pendangkalan sungai-sungai dan danau yang berlangsung terus karena proses erosi akibat penggundulan hutan sehingga tidak dapat menampung lagi luapan air hujan. Sementara tanah tidak mampu lagi menyerap air secara maksimal maka terjadilah banjir dimana-mana.

Banjir dapat terjadi karena curah hujan yang tinggi, intensitas, atau kerusakan akibat penggunaan lahan yang salah. Peranan penelusuran banjir (flood routing) yang merupakan bagian analisis hidrologi menjadi cukup tinggi. Penelusuran banjir bisa ditafsirkan sebagai prosedur untuk menentukan/memperkirakan waktu dan besaran banjir disuatu titik berdasarkan data yang diketahui (Sulianti, 2008).

Daerah aliran sungai (DAS) ini merupakan daerah rawan banjir pada saat musim penghujan datang, banyak hal yang menyebabkan daerah ini rawan banjir salah satunya perubahan tata guna lahan disekitar aliran sungai Krueng Meureubo. Untuk mengatasi hal tersebut dibutuhkan langkah-langkah penanggulangan yang tepat, antara lain dengan penelusuran debit banjir. Peranan penelusuran banjir (flood routing) yang merupakan bagian analisis hidrologi menjadi cukup tinggi. Penelusuran banjir dapat disebut sebagai suatu prosedur untuk memperkirakan/meramalkan waktu dan besaran banjir yang akan terjadi di suatu titik berdasarkan pada data yang diketahui. Penelusuran banjir (flood routing) adalah merupakan prakiraan hidrograf disuatu titik pada suatu aliran atau bagian sungai yang didasarkan atas pengamatan hidrograf di titik lain.

Salah satu tujuan penelusuran banjir adalah untuk peringatan dini banjir, salah satu metode yang terkenal dikembangkan oleh Muskingum. Untuk menghormati penemunya, metode tersebut dinamai Muskingum. Metode ini telah diterapkan secara intensif pada beberapa sungai di Inggris. Muskingum termasuk metode yang akurat, tingkat kesalahan prediksinya rata-rata sebesar 14 persen dan kesalahan prediksi waktu debit puncak rata-rata 0,16 jam. Metode Muskingum tidak didasarkan atas hukum-hukum dasar hidrolika. Metode ini hanya meninjau hukum kontinuitas dan tampungan. Metode Muskingum menggunakan data debit masuk dan debit keluar yang diukur pada waktu yang bersamaan.

\section{METODE PENELITIAN}

Metode pengumpulan data pada penelitian ini didapatkan dari Instansi-instansi terkait dan data yang diperoleh tersebut merupakan data sekunder. Data sekunder merupakan data pendukung yang di ambil dari instansi-instansi terkait yang berfungsi sebagai pendukung dalam perhitungan yang akan dilakukan. metode untuk menurunkan hidrograf satuan sintetik (HSS) digunakan metode Nakayasu, sedangkan Metode penelusuran aliran yang digunakan yaitu metode Muskingum.

Hidrograf adalah kurva yang memberi hubungan antara parameter aliran dan waktu. Parameter tersebut biasa berupa kedalaman aliran atau debit aliran, sehingga terdapat dua macam hidrograf yaitu hidrograf muka air dan hidrograf debit. Hidrograf muka air dapat ditransformasikan menjadi hidrograf debit dengan menggunakan rating curve. Untuk selanjutnya yang dimaksud dengan hidrograf debit. Hidrograf mempunyai tiga komponen pembentuk yaitu, aliran permukaan, aliran antara, dan aliran air tanah. Hitungan hidrograf satuan hanya dilakukan terhadap komponen limpasan permukaan. Oleh karena itu perlu memisahkan hidrograf terukur menjadi limpasan 
langsung dan aliran dasar. Aliran antara (interflow) adalah termasuk aliran dasar. Ada beberapa cara yang dapat dilakukan, diantaranya adalah metode garis lurus (straight line method), metode panjang dasar tetap (fixed based method), dan metode kemiringan berbeda (variable slope method) (Triadmodjo, 2010).

Hidrograf Satuan Sintetik (HSS) Nakayasu merupakan suatu cara untuk mendapatkan hidrograf banjir rancangan dalam suatu DAS. Untuk membuat suatu hidrograf banjir pada sungai, perlu dicari karakteristik atau parameter daerah pengaliran tersebut. Adapun karakteristik tersebut adalah:

a. Tenggang waktu dari permulaan hujan sampai puncak hidrograf (time to peak magnitute).

b. Tenggang waktu dari titik berat hujan sampai titik berat hidrograf (time log).

c. Tenggang waktu hidrograf ( time base of hydrograf).

d. Luas daerah pengaliran.

e. Panjang alur sungai utama (lenght of the longest channel).

Persamaan Hidrograf Satuan Sintetik Nakayasu :

$\mathrm{Qp}=\frac{1}{3.6} \frac{A . R}{0.3 T+\mathrm{T} 0.3}$

$\mathrm{Tp}=\mathrm{Tg}+0.8 \mathrm{Tr}$

$\mathrm{T}_{0.3}=\alpha \mathrm{Tg}$

$\mathrm{Tg}=0.4+0.058 \mathrm{~L} \quad \rightarrow$ untuk $\mathrm{L}>15 \mathrm{~km}$

$\mathrm{Tg}=0.21 \mathrm{~L}^{0,7} \rightarrow$ untuk $\mathrm{L}<15 \mathrm{~km}$

Dengan:

Qp : debit puncak banjir $\left(\mathrm{m}^{3} /\right.$ detik)

A : luas DAS $\left(\mathrm{km}^{2}\right)$

Re : curah hujan efektif (mm)

Tp : waktu dari permulaan banjir sampai puncak hidrograf banjir (jam)

$\mathrm{T}_{0.3}$ : waktu yang diperlukan oleh penurunan debit, dari debit puncak sampai menjadi $30 \%$ dari debit puncak (jam).

Tg : waktu konsentrasi

$\operatorname{Tr} \quad$ : satuan waktu dari curah hujan (jam)

$\alpha \quad$ : koefisien karakteristik DAS

$\mathrm{L} \quad$ : panjang sungai utama $(\mathrm{km})$

Persamaan kurva hidrograf satuan sintetisnya adalah :

a. Bagian melengkung naik untuk $0 \leq \mathrm{t} \leq \mathrm{Tp}$,

$\mathrm{Qa}=\mathrm{QP}\left\lfloor\frac{t}{\mathrm{Tp}}\right\rfloor^{2.4}$

b. Bagian lengkung turun :

Untuk $\mathrm{Q}_{\mathrm{d}}>0.3 \mathrm{QP} \quad$ untuk $\mathrm{TP}=\mathrm{t}<\mathrm{T} 0.3$

$\mathrm{Q}_{\mathrm{d}}=\mathrm{Q}_{\mathrm{p}} \cdot 0,3\left(\frac{t-T}{T 0,3}\right)$

Untuk 0,3 $\mathrm{Q}_{\mathrm{p}}>\mathrm{Q}_{\mathrm{d}}>0,3^{2} \mathrm{Q}_{\mathrm{d}} \quad$ untuk $\mathrm{T}_{0,3} \leq \mathrm{t} \leq 1,5 \mathrm{~T}_{\mathrm{p}}$

$\mathrm{Q}_{\mathrm{d}}=\mathrm{Q}_{\mathrm{p}} \cdot 0,3\left[\frac{(t-T)+1,5 T 0,3}{2,3}\right]$

Untuk $0,32 \mathrm{Q}_{\mathrm{p}}>\mathrm{Q}_{\mathrm{d}} \quad$ untuk $\mathrm{t} \leq 1,5 \mathrm{~T}_{0,3}$

Hubungan antara bentuk daerah pengaliran dengan T0,3 dapat dinyatakan :

$\mathrm{T}_{0,3}=0,47(A . L)^{0,25}$

Dengan :

$\mathrm{T}_{0,3}=\alpha \cdot \operatorname{tg}$ 
Maka :

$\alpha=\frac{T 0,3}{t}$

$\alpha=\frac{0,4(A \cdot L) 0,2}{t}$

dimana :

$\mathrm{Q}_{\mathrm{a}} \quad=$ limpasan sebelum mencapai debit puncak ( $\mathrm{m}^{3} /$ detik $)$

$\mathrm{Q}_{\mathrm{d}} \quad=$ limpasan sesudah mencapai debit puncak $\left(\mathrm{m}^{3} / \mathrm{detik}\right)$

$\mathrm{t} \quad=$ waktu (jam)

$\mathrm{L} \quad=$ panjang alur sungai $(\mathrm{km})$

$\operatorname{tg} \quad=$ waktu konsentrasi (jam)

$\alpha \quad=$ konstanta

Metode Muskingum dikembangkan oleh McCarthy (1938) dalam persamaan kontinuitas dan ditentukan oleh sebuah penyimpanan inflow dan outflow. Di dalam sebuah penyimpanan dapat menjangkau waktu perjalanan aliran yang sangat singkat, (Bedient and Huber, 2002).

$\frac{1}{2}\left(I_{1}+I_{2}\right)-\frac{1}{2}\left(0_{1}+0_{2}\right)=\frac{s-s}{\Delta}$

Inflow dan outflow saling berkaitan, untuk $a y^{\mathrm{n}}$ dari persamaan manning, dimana a dan $\mathrm{n}$ konstan.penyimpanan dalam tampungan sangat berkaitan untuk $b y^{\mathrm{m}}$, dimana $\mathrm{b}$ dan $\mathrm{m}$ konstan. Parameter $X$ merupakan koefisien pemberat dari inflow dan outflow dalam menentukan volume penyimpanan (Bedient and Huber, 2002).

Menurut Sobriyah dan Sudjarwadi (2000), Penelusuran banjir metode Muskingum telah diketahui dengan baik, dalam metode Muskingum, debit inflow dan outflow pada penggal sungai yang ditinjau, dijelaskan dalam persamaan kontinuitas sebagai berikut :

$\mathbf{I}=\mathbf{O}+\frac{d}{d}$

Dan dalam persamaan tampungan empiris $\mathrm{S}$ dinyatakan sebagai berikut :

$\mathbf{S}=\mathbf{K}[\mathbf{X I}-(\mathbf{I}-\mathbf{X}) \mathbf{O}]$

Dimana :

$\mathrm{I}=$ Debit inflow $(\mathrm{m} / \mathrm{dtk})$

$\mathrm{O}=$ Debit Outflow $(\mathrm{m} / \mathrm{dtk})$

$\mathrm{S}=$ Tampungan $(\mathrm{m})$

$\mathrm{K}=$ Koefisien tampungan $(\mathrm{dtk})$

$\mathrm{X}=$ Faktor pembobot

Prinsip dasar penyeselesaian perhitungan banjir dengan metode Muskingum adalah kelengkapan data pengukuran debit pada bagian hulu dan hilir sungai yang didapatkan pada waktu yang bersamaan. Pengukuran ini sangat penting untuk mendapatkan nilai tampungan yang terjadi pada penampang sungai yang ditinjau. Nilai ini yang akan digunakan untuk menentukan nilai $x$ dan $k$ (Arifiani, dkk, 2008).

Di lapangan biasanya nilai $x$ bervariasi antara 0.1 dan 0.3 . Nilai $k$ dan $x$ dapat diperoleh dengan kalibrasi hidrograf aliran masuk dan keluar. Apabila nilai $k$ dan $x$ telah diketahui, maka dapat digunakan untuk menghitung $S$ (Triadmodjo. 2010).

Lengkung $S$ adalah merupakan lengkung massa dari lengkung $I-Q$, sehingga untuk setiap saat dapat dihitung $S$. $S$ akan maksimum bila $I$ - $Q$ sama dengan 0 . Besarnya $S$ pada saat $t$ adalah : 
Vol. 4 No.1 April 2018

pp. $52-61$

$\mathbf{S}_{\mathrm{t}}=\boldsymbol{\Sigma}(\mathbf{I}-\mathbf{Q})_{1} \Delta \mathrm{t}$

Nilai $\boldsymbol{x}$ dan $k$ dapat diperoleh dengan menggambar grafik yang menyatakan hubungan antara S dan $x . I+(I-x) \cdot Q$, yaitu dengan memasukkan berbagai harga $x$ sedemikian rupa hingga didapat garis yang mendekati garis lurus.

Pada penelitian ini untuk mendapatkan garis lurus tersebut dilakukan dengan membuat sebuah program komputer, maka sambil memberikan berbagai harga $x$, diperiksa pula koefisien korelasi antara $r$ antara $S$ dengan x.I + (1 - x).Q, sampai didapatkan $r$ yang terbesar. Bila $r$ terbesar mempunyai harga lebih kecil dari 0,7 berarti tidak ada korelasi antara kedua faktor tersebut, sehingga tidak mungkin ditemukan garis lurus. Rumus untuk mendapatkan koefisen korelasi /' adalah sebagai berikut:

$$
\mathbf{r}=\frac{n \sum(X Y)-\Sigma Y \sum X}{\sqrt{\left[n \Sigma(Y)^{2}-(\Sigma Y)^{2}\right] \cdot\left[n \Sigma(X)^{2}-(\Sigma X)^{2}\right]}}
$$

dengan $\mathrm{X}=\mathrm{S}$, x.I+(1-x).Q, $n$ adalah banyaknya titik untuk dihitung harga $\mathrm{X}=\mathrm{S}$ dan X.I + (1-x). Q nya

$$
k=\tan \phi=\frac{S}{x \cdot 1+(1-x) \cdot \varphi}
$$

Jika dimasukkan harga $x$ yang tidak betul akan didapat suatu loop, yaitu pada $x=x 2$. Konstanta $k$ dan $x$ yang didapat tersebut hanyalah berlaku untuk bagian memanjang alur sungai yang ditinjau saja. Jika diketahui hidrograf debit masuknya, maka dapat diramalkan bentuk hidrograf keluarnya.

$\boldsymbol{O}_{j+1}=C_{0} I_{j+1}+C_{1} I_{j}+C_{2} O_{j}$

\section{HASIL DAN PEMBAHASAN}

Data curah hujan yang digunakan adalah data curah hujan bulanan maksimum tiap tahun dari stasiun penakar hujan. Curah hujan bulanan maksimum selama 10 tahunan yaitu dari 20052014. Untuk lebih jelasnya dapat dilihat pada Tabel 1

\begin{tabular}{|c|c|c|c|c|c|c|c|c|c|c|c|c|c|}
\hline \multirow[t]{2}{*}{ Tahun } & \multicolumn{12}{|c|}{ Bulan } & \multirow{2}{*}{ Max } \\
\hline & Jan & $\overline{P e b}$ & Mar & $\overline{A p r}$ & Mei & Jun & Jul & $\overline{\mathrm{Ags}}$ & Sep & $0 \mathrm{kt}$ & Nop & Des & \\
\hline 2005 & 43 & 73 & 106 & 83 & 68 & 37 & 48 & 46 & 85 & 53 & 72 & 56 & 106 \\
\hline 2006 & 50 & 70 & 52 & 42 & 19 & 54 & 66 & 65 & 88 & 107 & 60 & 31 & 107 \\
\hline 2007 & 39 & 41 & 31 & 37 & 50 & 37 & 60 & 101 & 35 & 135 & 42 & 94 & 135 \\
\hline 2008 & 94 & 100 & 31 & 95 & 94 & 40 & 96 & 90 & 96 & 75 & 77 & 69 & 100 \\
\hline 2009 & 25 & 63 & 96 & 88 & 100 & 66 & 45 & 59 & 95 & 45 & 75 & 26 & 100 \\
\hline 2010 & 91 & 56 & 69 & 96 & 72 & 50 & 30 & 40.5 & 100.5 & 58 & 65 & 80 & 100.5 \\
\hline 2011 & 71.5 & 50 & 90.5 & 105 & 55 & 40 & 90 & 90 & 50.5 & 90.5 & 90 & 90 & 105 \\
\hline 2012 & 90 & 100 & 100 & 74.5 & 45.5 & 75 & 93 & 48 & 51 & 106.5 & 76 & 90 & 106.5 \\
\hline 2013 & 78.5 & 80.5 & 60.5 & 72.5 & 70.5 & 45.5 & 15.5 & 65.5 & 25 & 15 & 85.5 & 80.5 & 85.5 \\
\hline 2014 & 84 & 96 & 125 & 65 & 51 & 82 & 58 & 146 & 71 & 98 & 96 & 59 & 146 \\
\hline
\end{tabular}

Tabel 1. Data curah hujan bulanan maksimum

Perhitungan curah hujan bulanan maksimum dilakukan secara manual. Tujuan menghitung curah hujan maksimum ini yaitu untuk mendapatkan debit air hujan maksimum yang nantinya digunakan untuk menghiutung intensitas curah hujan. Dari tabel 4.2 dapat kita lihat curah hujan bulanan maksimum yang paling tinggi terjadi pada tahun 2014 hingga mencapai $146 \mathrm{~mm} / \mathrm{dt}$. 
Vol. 4 No.1 April 2018

pp. $52-61$

\section{a. Analisis Frekuensi}

Untuk meramal curah hujan rencana dilakukan dengan analisis frekuensi data hujan. metode analisis frekuensi yang digunakan pada penelitian ini yaitu distribusi Log Pearson Tipe III atau Distribusi Extrim Tipe III digunakan untuk analisis variabel hidrologi dengan nilai varian minimum misalnya analisis frekwensi distribusi dari debit minimum (low flows). Distribusi Log Pearson Tipe III, mempunyai koefisien kemencengan (Coefisien of skwennes) atau $\mathrm{CS} \neq 0$.

Tabel 2. Perhitungan curah hujan rencana distribusi log person tipe III

\begin{tabular}{|c|c|c|c|c|c|c|c|}
\hline \multicolumn{8}{|c|}{ Metode Log person III } \\
\hline No & Tahun & $\mathbf{x}$ & $\log X$ & $\begin{array}{c}(\log x- \\
\text { Log Xbar })\end{array}$ & $\begin{array}{c}(\log x-\log \\
\mathrm{Xbar}^{\wedge} 2\end{array}$ & $\begin{array}{c}(\log x- \\
\log \\
{\text { Xbar })^{\wedge} 3}\end{array}$ & $\begin{array}{c}(\log x- \\
\log \\
{\text { Xbar })^{\wedge} 4}\end{array}$ \\
\hline 1 & 2005 & 106 & 2.0253 & -0.0079 & 0.0001 & 0.0000 & 0.0000 \\
\hline 2 & 2006 & 107 & 2.0294 & -0.0038 & 0.0000 & 0.0000 & 0.0000 \\
\hline 3 & 2007 & 135 & 2.1303 & 0.0971 & 0.0094 & 0.0009 & 0.0001 \\
\hline 4 & 2008 & 100 & 2.0000 & -0.0332 & 0.0011 & 0.0000 & 0.0000 \\
\hline 5 & 2009 & 100 & 2.0000 & -0.0332 & 0.0011 & 0.0000 & 0.0000 \\
\hline 6 & 2010 & 101 & 2.0022 & -0.0310 & 0.0010 & 0.0000 & 0.0000 \\
\hline 7 & 2011 & 105 & 2.0212 & -0.0120 & 0.0001 & 0.0000 & 0.0000 \\
\hline 8 & 2012 & 106.5 & 2.0273 & -0.0059 & 0.0000 & 0.0000 & 0.0000 \\
\hline 9 & 2013 & 85.5 & 1.9320 & -0.1012 & 0.0102 & -0.0010 & 0.0001 \\
\hline 10 & 2014 & 146 & 2.1644 & 0.1311 & 0.0172 & 0.0023 & 0.0003 \\
\hline Jumlah & & 1092 & 20.332 & 0.0000 & 0.0403 & 0.0020 & 0.0005 \\
\hline Rata-rata & & 109.15 & 2.0332 & 0.0000 & 0.0040 & 0.0002 & 0.0000 \\
\hline $\mathrm{S} \log$ & 0.0669 & & & & & & \\
\hline Cs log & 0.9402 & & & & & & \\
\hline Cv log & 0.0006 & & & & & & \\
\hline $\mathrm{Ck} \log$ & 0.2286 & & & & & & \\
\hline
\end{tabular}

Dari hasil perhitungan yang telah dilakukan didapat hasil $\mathrm{Cs}=0,9402$ dan nilai $\mathrm{Ck}=$ 0,2286 . Setelah melakukan perhitungan ini kemudian menghitung curah hujan rencana distribusi log person III. Untuk lebih jelasnya dapat dilihat pada Tabel 3.

Tabel 3. Perhitungan curah hujan rencana distribusi log person tipe III

\begin{tabular}{|c|c|c|c|c|c|}
\hline $\begin{array}{c}\mathrm{T} \\
\text { (tahun) }\end{array}$ & $\begin{array}{c}\mathrm{P}_{\mathrm{T}} \\
(\%)\end{array}$ & $\mathrm{G}$ & G.s & $\log \mathrm{RT}$ & $\begin{array}{c}\mathrm{RT} \\
(\mathrm{mm})\end{array}$ \\
\hline$(1)$ & $(2)$ & $(3)$ & $(4)$ & $(5)$ & $(6)$ \\
\hline 2 & 5 & -0.154 & -0.010 & 2.023 & 105.407 \\
\hline 5 & 2 & 0.765 & 0.051 & 2.084 & 121.443 \\
\hline 10 & 1 & 1.339 & 0.090 & 2.123 & 132.678 \\
\hline
\end{tabular}


Berdasarkan Tabel 3 dapat dilihat besarnya debit hujan dalam periode ulang (T). Pada tabel tersebut juga menjelaskan debit hujan yang paling tinggi terjadi pada periode ulang 10 tahunan yaitu mencapai $132,678 \mathrm{~mm} / \mathrm{jam}$.

\section{b. Metode Hidrograf Satuan Nakayasu}

Bedasarkan hasil analisis yang disuguhkan pada Tabel 4 dapat dilihat besarnya intensitas curah hujan dengan durasi 24 jam dengan periode ulang 2 tahunan, 5 tahunan dan 10 tahunan. Dari tabel tersebut dapat dilihat besarnya intensitas curah hujan yang tertinggi terjadi pada periode ulang 10 tahunan dan terendah terjadi pada periode ulang 2 tahunan. Nilai intensitas curah hujan ini nantinya digunakan dalam perhitungan Metode Hidrograf Satuan Sintetik Nakayasu.

Tabel 4. Satuan Sintetik Nakayasu

\begin{tabular}{|c|c|c|c|c|}
\hline \multirow{2}{*}{$\mathrm{t}(\mathrm{Jam})$} & $\begin{array}{c}\text { RT } \\
\text { (2 th) }\end{array}$ & $\begin{array}{c}\text { RT } \\
(5 \text { th })\end{array}$ & RT $\quad(10$ th $)$ & \multirow{2}{*}{ inflow (Q) } \\
\hline & 105,407 & 121,443 & 132,678 & \\
\hline 0 & 0,000 & 0,000 & 0,000 & 0,000 \\
\hline 1 & 36,543 & 42,102 & 45,997 & 124,642 \\
\hline 1,275 & 31,078 & 35,806 & 39,119 & 106,004 \\
\hline 2 & 23,020 & 26,523 & 28,976 & 78,519 \\
\hline 3 & 17,568 & 20,240 & 22,113 & 59,921 \\
\hline 4 & 14,502 & 16,708 & 18,254 & 49,464 \\
\hline 5 & 12,497 & 14,399 & 15,731 & 42,627 \\
\hline 6 & 11,067 & 12,751 & 13,930 & 37,748 \\
\hline 7 & 9,986 & 11,505 & 12,570 & 34,062 \\
\hline 7,648 & 9,414 & 10,846 & 11,849 & 32,109 \\
\hline 8 & 9,136 & 10,525 & 11,499 & 31,160 \\
\hline 9 & 8,446 & 9,731 & 10,631 & 28,807 \\
\hline 10 & 7,873 & 9,071 & 9,910 & 26,853 \\
\hline 11 & 7,388 & 8,512 & 9,300 & 25,200 \\
\hline 12 & 6,972 & 8,032 & 8,776 & 23,780 \\
\hline 13 & 6,610 & 7,615 & 8,320 & 22,544 \\
\hline 14 & 6,291 & 7,248 & 7,919 & 21,457 \\
\hline 14,021 & 6,285 & 7,241 & 7,911 & 21,436 \\
\hline 15 & 6,008 & 6,922 & 7,563 & 20,493 \\
\hline 16 & 5,755 & 6,631 & 7,244 & 19,630 \\
\hline 17 & 5,527 & 6,368 & 6,957 & 18,852 \\
\hline 18 & 5,320 & 6,130 & 6,697 & 18,147 \\
\hline 19 & 5,132 & 5,913 & 6,460 & 17,505 \\
\hline 20 & 4,960 & 5,714 & 6,243 & 16,916 \\
\hline Max & 36,543 & 42,102 & 45,997 & 124,642 \\
\hline
\end{tabular}


Vol. 4 No.1 April 2018

pp. $52-61$

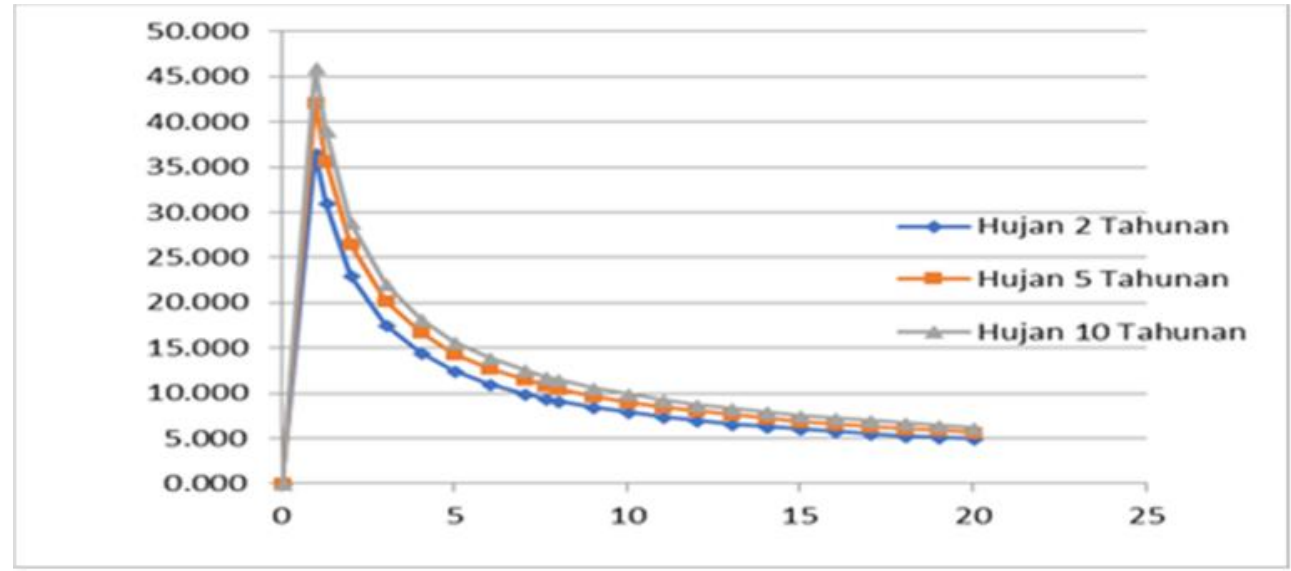

Gambar 1. Hidrograf Banjir Rancangan HSS Nakayasu

Perhitungan debit banjir rencana dengan metode HSS Nakayasu memerlukan data intensitas curah hujan dalam durasi dan periode ulang tertentu yang dapat diperoleh dari data curah hujan harian, bertujuan untuk memperkirakan debit puncak yang terjadi.

\section{c. Hidrograf Penelusuran Banjir dengan Metode Muskingum}

Pada metode ini data debit inflow yang di ambil data debit hujan 2 Tahunan, kemudian di cari nilai debit outflow dengan menggunakan metode muskingum, yang dimasukkan adalah nilai masuk inflow yaitu nilai outflow sama dengan nilai awal.

Tabel 5. Metode Muskingum

\begin{tabular}{|c|c|c|c|c|c|}
\hline \multirow{2}{*}{ t (Jam) } & \multirow{2}{*}{$\begin{array}{l}\text { inflow } \\
\text { (Q) }\end{array}$} & \multirow{2}{*}{ clij } & \multirow{2}{*}{$\mathrm{c} 2 \mathrm{ij}$} & \multirow{2}{*}{ c3qj } & outflow \\
\hline & & & & & Q \\
\hline 0 & 0,000 & & & & 0,000 \\
\hline 1 & 36,543 & 2,297 & 0 & 0 & 2,297 \\
\hline 1,275 & 31,078 & 1,954 & 33,9621 & 0,0178 & 35,934 \\
\hline 2 & 23,020 & 1,447 & 28,8838 & 0,27836 & 30,609 \\
\hline 3 & 17,568 & 1,105 & 21,3948 & 0,23711 & 22,736 \\
\hline 4 & 14,502 & 0,912 & 16,3273 & 0,17612 & 17,415 \\
\hline 5 & 12,497 & 0,786 & 13,4779 & 0,1349 & 14,398 \\
\hline 6 & 11,067 & 0,696 & 11,6149 & 0,11154 & 12,422 \\
\hline 7 & 9,986 & 0,628 & 10,2855 & 0,09623 & 11,010 \\
\hline 7,648 & 9,414 & 0,592 & 9,28102 & 0,08528 & 9,958 \\
\hline 8 & 9,136 & 0,574 & 8,74908 & 0,07714 & 9,401 \\
\hline 9 & 8,446 & 0,531 & 8,49052 & 0,07282 & 9,094 \\
\hline 10 & 7,873 & 0,495 & 7,84933 & 0,07045 & 8,415 \\
\hline 11 & 7,388 & 0,465 & 7,31691 & 0,06518 & 7,847 \\
\hline 12 & 6,972 & 0,438 & 6,86645 & 0,06078 & 7,366 \\
\hline 13 & 6,610 & 0,416 & 6,47948 & 0,05706 & 6,952 \\
\hline 14 & 6,291 & 0,396 & 6,14278 & 0,05385 & 6,592 \\
\hline 14,021 & 6,285 & 0,395 & 5,84667 & 0,05107 & 6,293 \\
\hline 15 & 6,008 & 0,378 & 5,84083 & 0,04875 & 6,267 \\
\hline 16 & 5,755 & 0,362 & 5,58384 & 0,04855 & 5,994 \\
\hline 17 & 5,527 & 0,347 & 5,34869 & 0,04643 & 5,743 \\
\hline 18 & 5,320 & 0,335 & 5,13683 & 0,04448 & 5,516 \\
\hline 19 & 5,132 & 0,323 & 4,94477 & 0,04273 & 5,310 \\
\hline 20 & 4,960 & 0,312 & 4,76971 & 0,04113 & 5,123 \\
\hline Max & 36,543 & & & & 35,934 \\
\hline Nilai Rata2 & 10,724 & & & & 10,529 \\
\hline
\end{tabular}


Vol. 4 No.1 April 2018

pp. $52-61$

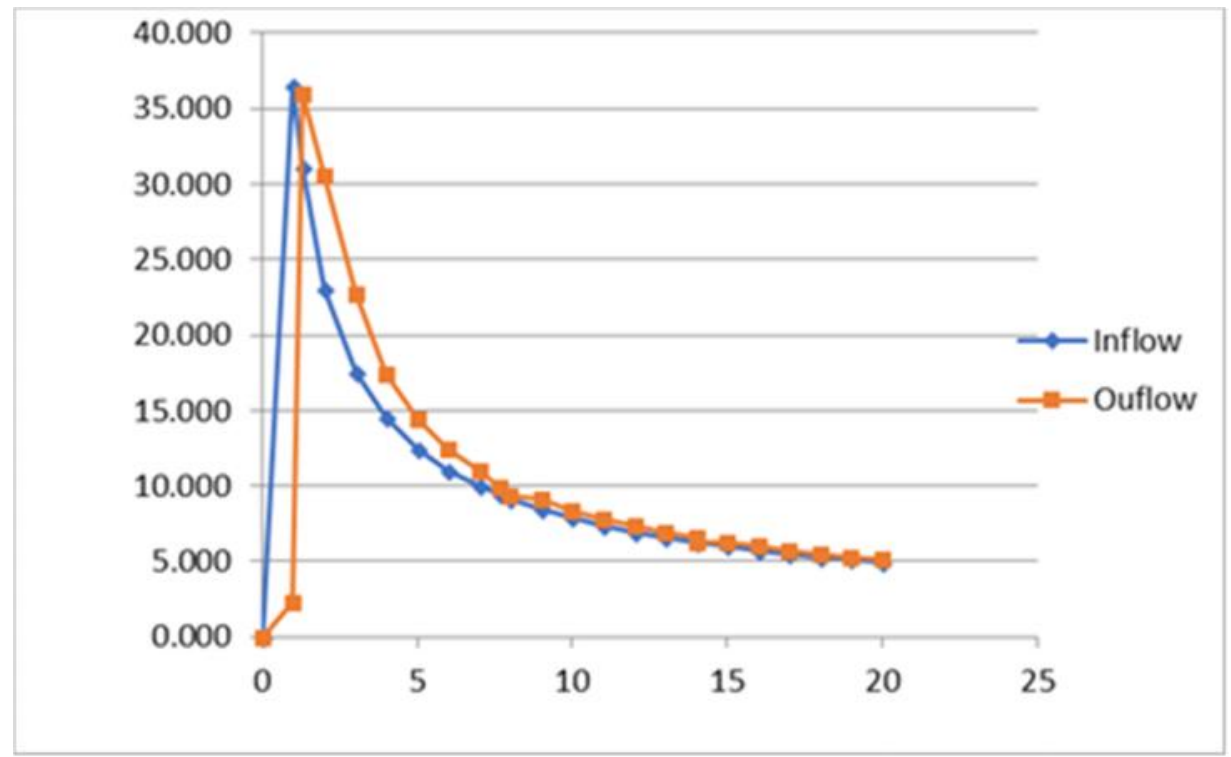

Gambar 2. Hidrograf Sub DAS Krueng Meureubo.

Pada Gambar 2. Berdasarkan Nilai debit puncak inflow di dapat $36,543 \mathrm{~m}^{3} / \mathrm{s}$, sedangkan nilai debit puncak outflow 35,934 $\mathrm{m}^{3} / \mathrm{s}$. Hidrograf aliran dengan metode Muskingum tersebut tampak bahwa perbedaan nilai awal masukan outflow tidak berpengaruh besar terhadap debit yang dihasilkan, nilai debit yang dihasilkan hampir sama hingga akhir hidrograf.

\section{KESIMPULAN}

1. Data debit inflow yang di ambil data debit hujan 2 Tahunan, kemudian di cari nilai debit outflow dengan menggunakan metode muskingum, yang dimasukkan adalah nilai masuk inflow yaitu nilai outflow sama dengan nilai awal.

2. Nilai debit puncak inflow di dapat $36,543 \mathrm{~m}^{3} / \mathrm{s}$, sedangkan nilai debit puncak outflow 35,934 $\mathrm{m}^{3} / \mathrm{s}$. Hidrograf aliran dengan metode Muskingum tersebut tampak bahwa perbedaan nilai awal masukan outflow tidak berpangaruh besar terhadap debit yang dihasilkan.

3. Nilai nilai Koefisien $(K) 3400 \mathrm{~s}$ dan nilai $X$ didapat 0,462 pada aliran hidrogfar aliran. $\mathrm{C} 1=$ $0,063, \mathrm{C} 2=0,929$, dan $\mathrm{C} 3=0,008$. Dimana nilai $\mathrm{C} 1+\mathrm{C} 2+\mathrm{C} 3=1$. Pada dasarnya nilai koefisien kekasaran sepanjang sungai bervariasi.

\section{SARAN}

1. Pada penelitian selanjutnya perlu dilakukan juga kalibrasi perubahan profil penampang sungai, sehingga setiap kali terjadi perubahan debit aliran sungai kita dapat mengetahui bentuk perubahan profil penampang sungai yang terjadi.

2. Untuk pihak-pihak terkait terutama yang menangani tentang mitigasi bencana dapat melihat kondisi ini sebagai acuan untuk melakukan tindak lanjut akan pengurangan resiko bencana banjir. 
Vol. 4 No.1 April 2018

pp. $52-61$

\section{DAFTAR PUSTAKA}

[1] Arifiani, Nur, dkk. 2008. Kajian Debit Banjir Pada Daerah Aliran Sungai Tulang Bawang Dengan Metode Kinematis Muskingum Universitas Lampung, Bandar Lampung.

[2] Bedient, Philip B., and Huber Wayne C. 2002. Hydrology and Floodplain Analysis, University Of Florida.

[3] Sobriyah., dkk. 2014. Analisis Hidrograf Aliran Daerah Aliran Sungai Keduang Dengan Beberapa Metode Hidrograf Satuan Sintetis. E-Jurnal Matriks Teknik Sipil, Surakarta.

[4] Sulianti, Ika. 2008. Perbandingan Beberapa Metode Penelusuran Banjir Secara Hidrologi (Studi Kasus Sungai Belitang di Sub DAS Komering). Jurnal Sipil Vol.3. No.1

[5] Triatmodjo, B. 2010. Hidrologi Terapan. Beta Offset. Yogyakarta. 